\title{
ANALISIS MULTIVARIAT KETIDAKPUASAN DALAM SEKTOR KESEHATAN DI DAERAH ISTIMEWA YOGYKARTA
}

\author{
ASEP ROKHYADI \\ Program Studi Manajemen Universitas Mercu Buana Yogyakarta \\ Email: asep.rokhyadi@gmail.com
}

ADELIA EKA PUTRI

Prodi Manajemen Universitas Mercu Buana Yogyakarta Email: ekaputri adelia@yahoo.com

\begin{abstract}
The dissatisfaction of the service is a thing that it is not desired by service users. That service providers always and continue to make improvements in the services provided, it can reduce the user of the dissatisfaction. The dissatisfaction of this service is an influenced location service, service failure, the complaints, and also skills. The agencies who using services in the health sector is all of the Regional Hospital located in Yogyakarta. The purpose of this study is to analyze what the location indicator, service failures, complaints and skills have the influence forward the dissatisfaction in the health sector.
\end{abstract}

In this research abaout the dissatisfaction of the services to the health sector using the sampling method is the proportional random sampling. The population of the research are all of people who have ever felt of the service in the region hospital in Yogyakarta especially, with a total sample of 100 respondents.

The collecting of data's were to analyzed using the basic assumption (normality), the classical assumption test (multicollinearity, heteroscedasticity, independence/autocorrelation) and multiple linear regression ( $F$ test, $t$ test). Based on the results of data analysis it can be concluded that the partial (t test), there are 3 indicators (1) locations (0.974) (2) service failure (0.798) (3) skills (0.162) it indicators that was not have a strong influence to the dissatisfaction. The hypothesis of test partial is independent variable just only significant indicator of the complaints $(0,000)$, because the significance of value less than 0.05 . the conclution of this research, indicators of complaints is an indicator of the most dominant among the others. Whereas the simultaneous hypothesis of testing from all

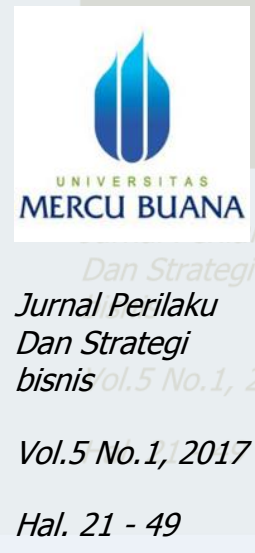

JPSB Vol.5 No.1, 2017 
of significant indicators, because the significance of value less than 0.05 .

Keywords : The dissatisfaction, Location, Failure of Service, Complaints, Skills, Services

\section{PENDAHULUAN}

Pelayanan yang baik merupakan hal utama yang selalu diinginkan oleh para pengguna jasa atau produk. Sebaiknya pemberi jasa selalu dan terus melakukan perbaikan terhadap pelayanan yang diberikan. Hal ini dapat memperkecil pengguna dari ketidakpuasan. Mengapa demikian, karena pelanggan tidak akan merasa puas jika apa yang mereka terima tidak

Demikian pula bidang kesehatan, yaitu pemenuhan atas rasa sembuh ketika pasien sedang berobat. Sekarang ini bukan hanya rumah sakit yang menjadi tujuan utama para pasien yang melakukan pengobatan akan tetapi juga puskesmas. Pada beberapa daerah faktor jarak merupakan prioritas yang lebih diutamakan oleh para pasien dalam berobat ketika sakit. Dalam keadaan sakit pasien enggan untuk pergi berobat jauh, menimbang keadaan kesehatan yang kurang baik. Hal ini lah yang menjadikan pasien lebih memilih tempat pengobatan yang lebih dekat dan tepat.

Selain indikator tersebut diatas yang tidak kalah penting adalah layanan. Apabila layanan yang pertama kali mereka jumpai berkesan buruk maka akan mengakibatkan kegagalan terhadap layanan. Kegagalan layanan mengacu pada kinerja pelayanan yang jatuh di bawah ekspektasi pelanggan (Hoffman dan Bateson, 1997), hal tersebut bisa diperkecil dengan adanya evaluasi langsung serta rutin terhadap buruknya pelayanan. Pelayanan dipandang buruk bilamana pasien merasakan apa yang seharusnya diperoleh oleh pasien tidak didapatkan. Terdapat deviasi ganda (Bitner et al., 1990), yang merupakan situasi dimana pelanggan merasakan ketidakpuasan terhadap layanan yang terjadi tidak hanya pada kegagalan layanan awal, namun juga pemulihan atas kegagalan layanan. Pemulihan layanan yang dilakukan perlu mempertimbangkan banyak faktor, bukan semata karena pasien namun juga mengingat kondisi rumah sakit dan semua staf-staf nya. Pemulihan layanan mengacu pada tindakan apa yang akan dilakukan oleh penyedia layanan dalam menanggapi kegagalan layanan (Gronroos, 1988), hal ini dimaksudkan untuk mengejar kembali pelanggan yang tidak puas agar menjadi puas (Berry dan Parasuraman, 1991). Dampak dari pelayanan buruk ini akan berujung pada keluhan pasien.

Ketika keluhan terjadi, rasa keadilanlah yang dinilai sangat penting untuk pemulihan layanan yang dapat menilai perilaku pelanggan di masa depan 
(Schoefer dan Diamantopoulos, 2008). Rasa keadilan inilah yang dapat mempengaruhi pelanggan dalam perilaku keluhan (Schoefer dan Diamantopoulos, 2008). Keluhan tidak selalu negatif, dalam pengertian keluhan ini dapat menjadi kritik membangun pada rumah sakit agar menjadi lebih baik. Perbaikan sistem ini bisa meningkatkan produktivitas rumah sakit kedepannya. Hal ini tersebut, melatari penangan keluhan yang diberikan dengan baik dapat memperoleh hasil yang baik pula. Keluhan yang ditangani dengan baik dapat memiliki dampak positif pada pengalaman pelanggan, sehingga membalikkan situasi dari negatif ke positif bagi pelanggan dan perusahaan (Blodgett et al., 1997). Pasien yang merasa tidak puas terhadap hasil layanan dapat dipastikan mereka akan melakukan tindakan yang mungkin tidak diinginkan oleh pihak rumah sakit, yaitu mengajukan keluhan. "Pengaduan penanganan" mengacu pada tindakan yang tegas untuk menanggapi cacat atau kegagalan dalam pemberian layanan (Gronroos, 1988). Penanganan keluhan ini penting untuk memuaskan dan mempertahankan pelanggan (Stauss dan Seidel, 1998). Keberhasilan penanganan pengaduan membutuhkan "situasi" yang tepat, yaitu situasi dimana keluhan itu ditangani dengan sesuai (Smith et al., 1999). Kita perlu memahami secara kritis mengenai perilaku karyawan dari titik pandang pelanggan jika nantinya kita akan memberikan kepuasan pelanggan (Winsted, 2000).

Keluhan pelanggan atas pelayanan yang diterima ini sangat dipengaruhi oleh ketrampilan karyawan dalam menyampaikan layanan. Rumah sakit selalu mengusahakan pelayanan yang maksimal kepada pasien. Bukan hanya itu saja, ketrampilan yang dimiliki oleh para staf medis juga menjadi salah satu perhatian khusus yang perlu di evaluasi. Karyawan harus dididik dalam mengubah pola gagasan mereka yaitu dalam artian "seharusnya" diutamakan untuk mengenali dan menangani kebutuhan pelanggan (Hart et al., 1990). Pelayanan yang baik itu didukung dengan ketrampilan para stafnya. Ketrampilan itulah yang secara langsung diterima para pasien ketika adanya interaksi staf dengan pasien. Ketrampilan ini bisa dilihat dari cara penanganan staf medis terhadap pasien, bagaimana waktu pelayanan, pelayanan yang menyenangkan, kesungguhan dalam memberikan pelayanan dan lain sebagainya. Ketrampilan para staf ini dapat menjadi penentu kepuasan terhadap pelayanan pasien.

Memperhatikan ketidakpuasan tersebut diatas, menjadi kendala utama bagi perusahaan. Sedangkan hasil dari ketidakpuasan tersebut yang melahirkan strategi lokasi, kegagalan pelayanan, keluhan, dan juga peningkatan ketrampilan karyawan. Hal inilah yang melatar belakangi diangkatnya penelitian ini dengan 
mengusung judul "Analisis Multifariat Indikator Lokasi, Kegagalan Layanan, Keluhan, dan Ketrampilan Pada Ketidakpuasan dalam Sektor Kesehatan di Daerah Istimewa Yogyakarta.

\section{RUMUSAN MASALAH}

Dari permasalahan yang telah muncul diatas maka dapat ditarik beberapa rumusan masalah, antara lain :

1. Apakah variabel lokasi, kegagalan layanan, keluhan, dan ketrampilan mempengaruhi ketidakpuasan dalam sektor kesehatan di rumah sakit DIY?

2. Dari variabel lokasi, kegagalan layanan, keluhan dan ketrampilan, variabel manakah yang paling dominan pada penelitian ini?

3. menjadi sebuah tambahan ilmu bagi masyarakat luas

\section{TEORI DAN PENGEMBANGAN HIPOTESIS}

\section{Lokasi}

Dalam kegunaan tempat (place utility), kegunaan ini diperoleh konsumen karena dengan pemasaran, produk dibuat pada tempat yang dapat didatangi konsumen (Simamora, 2001). penentuan lokasi tidak konstan, tapi berubah seiring waktu sesuai dengan perubahan dalam hukum, peraturan, dan / atau kondisi pasar. Perubahan yang cepat di pasar global saat ini memaksa perusahaan untuk memeriksa kembali dan memperbaiki cara-cara mereka bersaing. Integrasi fasilitas keputusan lokasi dalam pemasaran global dan strategi manufaktur menyediakan sarana penting bagi perusahaan untuk bersaing di pasar global Canel dan Das (2002).

\section{Kegagalan layanan}

Service failure atau kegagalan layanan dapat terjadi karena banyak alasan, misalnya ketika jasa yang ditawarkan tidak tersedia sesuai dengan yang dijanjikan, ketika jasa disampaikan terjadi keterlambatan ataupun terlalu lama, dan hasil (jasa) mungkin saja tidak benar atau dilakukan dengan tidak benar, serta ketika karyawan melayani dengan kasar dan tidak peduli (Newman, 2001).

Bila terjadi kegagalan layanan, pelanggan mengalami berbagai emosi negatif. Reaksi emosional tertentu tergantung pada persepsi pelanggan tentang mengapa kegagalan layanan yang terjadi pada tempat awal mereka merasakan layanan yang telah diberikan (Walker, 2012). Beberapa orang menganggap kegagalankegagalan lainnya yang dirasakan oleh pelanggan menjadi tanggung jawab perusahaan ketika mereka melihat bahwa kegagalan berada di bawah kehendak kendali perusahaan (yaitu pengendalian atribusi) (Huang, 2008). Dengan 
memahami peran penting dari reputasi perusahaan, organisasi pelayanan memahami bahwa perlu berhati-hati dalam membangun dan menjaga reputasi sangat penting untuk sebuah kesuksesan, hal ini menunjukkan bahwa reputasi yang sangat baik secara langsung mempengaruhi bagaimana pelanggan merespon kegagalan (Nikbin et al., 2011).

\section{Keluhan}

Dalam menghadapi pelanggan yang mengeluh kita harus menyadari bahwa keluhan itu adalah salah satu langkah menuju perbaikan perusahaan. Keluhan pelanggan bukan berarti penghinaan terhadap produk perusahaan, melainkan merupakan suatu alat koreksi yang efektif yang akan membuat perusahaan semakin matang. Dengan adanya keluhan para petugas juga akan menjadi lebih profesional dalam bekerja (Sugiarto, 2002). Salah satu dari 4 metode untuk mengukur kepuasan pelanggan yang di kemukakan oleh Tjipto dan Chandra (2005), yaitu Sistem keluhan dan saran, yang diterangkan : Organisasi yang berorientasi pada pelanggan (Customer Oriented) perlu menyediakan kesempatan dan akses yang mudah dan nyaman bagi pelanggannya guna menyampaikan saran, kritik, pendapat dan keluhan mereka. Salah satu cara yang paling efisien untuk meningkatkan penanganan keluhan adalah proses komputerisasi (Mitchell, 1993).

\section{Ketrampilan}

Perusahaan yang sukses percaya bahwa hubungan pegawai akan berdampak pada hubungan pelanggan (Simamora, 2001). Namun yang juga harus dipertimbangkan adalah kemampuan karyawan, yang mana kemampuan karyawan merupakan garis depan yang penting untuk menyelesaikan penanganan keluhan pelanggan yang efektif (Huppertz, 2007). Pegawai yang bertugas menangani keluhan harus terlatih agar dapat menyelesaikan keluhan pelanggan dengan cepat dan memuaskan (Simamora, 2001). Keterampilan karyawan cepat menjadi aset yang paling berharga organisasi (Matsumoto et al., 2005). Cadman (2013) berargumen untuk memastikan bahwa karyawan memiliki keterampilan yang jauh lebih dari apa yang menjadi tugasnya, dan sekarang terbuka luas untuk bisa lebih mengasah kemampuan mereka, agar mempunyai kompetensi karyawan jangka panjang, bisa meminimalkan kecelakaan dan menciptakan keterampilan yang mencerminkan kebutuhan bisnis. Hasil dari pengembangan skala pengukuran menunjukkan bahwa orientasi pelayanan diwakili oleh kepemimpinan layanan, kontak layanan, manajemen sumber daya manusia, dan sistem pelayanan, sedangkan keterampilan layanan yang 
diwujudkan oleh keterampilan fungsional dan keterampilan teknis (Luk et al., 2013).

\section{Ketidakpuasan}

Konsumen yang tidak puas akan berusaha mengurangi ketidakpuasannya, karena dengan kodrat manusia "untuk menciptakan keserasian, konsistensi, dan keselarasan di antara pendapat, pengetahuan dan nilai-nilai di dalam dirinya." Konsumen yang tidak puas akan mengambil satu atau dua tindakan. Mereka mungkin akan mengurangi ketidakcocokannya dengan meninggalkan atau mengembalikan produk tersebut, atau mereka mungkin berusaha mengurangi ketidakcocokannya dengan mencari informasi yang mungkin mengkonfirmasikan produk tersebut sebagai bernilai tinggi (atau menghindari informasi yang mengkonfirmasikan prosuk tersebut sebagai bernilai rendah) (Setiadi, 2010). Kenyataan yang mereka dapat berbeda dari yang diharapkan, maka mereka merasa tidak puas (Simamora, 2001). Pelanggan yang tidak puas akan menghentikan pembelian produk yang bersangkutan dan kemungkinan akan menyebarkan berita tersebut pada teman-teman mereka (Setiadi, 2010). Konsumen yang tidak puas akan memperlihatkan kemungkinan untuk tidak membeli lagi produk, bahkan meneruskan informasi tersebut kepada orang lain disekitarnya, yang akan menyebabkan konsumen lainnya tidak menyukai produk tersebut (Simamora, 2001)

Berbagai pemaparan mengenai lokasi banyak bermunculan, seperti pendapat Simamora (2001) tempat merupakan magnet bagi konsumen, Bull (1994) lokasi menjadi pusat penggalian keuntungan, Canel dan Das (2002) keputusan lokasi dipandang sebagai sarana penting bagi perusahaan untuk bersaing di pasar global. Kesemuanya ini (Simamora, 2001; Bull, 1994; Canel dan Das, 2002) mempunyai hubungan pengaruh yang kuat pada ketidakpuasan pelayanan. Selain itu peneliti juga menjelaskan mengenai pentingnya lokasi sebagai faktor penting keberhasilan seperti Clarkson et al (1996). Dengan demikian, peneliti mengungkapkan hipotesa sebagai berikut

H1: terdapat pengaruh yang kuat antara lokasi dan ketidakpuasan layanan

Dari banyak penelitian, beberapa diantaranya yang mengangkat mengenai kegagalan layanan. Seperti : Newman (2001) kegagalan layanan terjadi karena terjadi keterlambatan layanan, Zeithaml dan bitner (2000) kegagalan layanan terjadi ketika layanan tidak sesuai persepsi pelanggan, Weun et al (2004) kegagalan layanan sejajar dengan masalah yang dialami, semakin sering atau semakin buruk kegagalan jasa, maka semakin besar persepsi kerugian yang 
diterima pelanggan. Kesemuanya ini mempunyai hubungan pengaruh yang kuat pada ketidakpuasan pelayanan. Dengan demikian, peneliti mengungkapkan hipotesa sebagai berikut :

H2: terdapat pengaruh yang kuat antara kegagalan layanan dan ketidakpuasan layanan

Beberapa diantara penelitian yang mengungkap tentang keluhan, seperti (Barlow \& Moller, 1996) keluhan merupakan belum terpenuhinya suatu harapan pelanggan, demikian halnya Majid (2009) keluhan muncul karena buruknya pelayanan seperti mereka merasa diacuhkan, tidak adanya yang bertanggung jawab atas kesalahan yang terjadi, Sugiarto (2002) beberapa sumber keluhan berasal dari pelanggan, karyawan, manajemen, pengunjung, para pemimpin perusahaan, rekanan bisnis, dan pesaing bisnis. Beberapa ulasan dari penelitipeneliti tersebutlah yang melahirkan pengaruh hubungan kuat dengan ketidakpuasan. Dengan demikian, peneliti mengungkapkan hipotesa sebagai berikut :

\section{H3: terdapat pengaruh yang kuat antara keluhan dan ketidakpuasan layanan}

Berbagai peneliti mengutarakan mengenai variabel ketrampilan, yang mengulas secara lebih detail. Seperti Huppertz (2007) kemampuan karyawan adalah garis depan, Simamora (2001) karyawan harus terlatih untuk menangani keluhan pelanggan, Matsumoto et al (2005) ketrampilan karyawan merupakan aset berharga. Kesemuanya ini mempunyai pengaruh hubungan yang kuat terhadap ketidakpuasan. Inilah yang membuat diharuskannya karyawan rumah sakit memiliki ketrampilan lebih dalam memberikan pelayanan. Namun, dalam beberapa layanan, partisipasi pelanggan diperlukan didalam keseluruhan selama proses berlangsung (Kelley et al, 1990), sedemikian rupa sehingga kebutuhan karyawan dalam beradaptasi dan keterampilan improvisasinya juga berlaku bagi pelanggan, terutama ketika layanan gagal dan perlu menenangkan pelanggan yang mengalami ketidakpuasan. Dengan demikian, peneliti mengungkapkan hipotesa sebagai berikut :

H4: terdapat pengaruh yang kuat antara ketrampilan dan ketidakpuasan layanan 


\section{METODE PENELITIAN}

\section{Populasi dan sampel}

Di dalam penelitian ini populasi yang dimaksudkan yaitu seluruh pasien yang pernah melakukan pengobatan atau yang pernah merasakan pelayanan di rumah sakit D.I Yogyakarta. Sedangkan sampel mereka yang pernah merasakan pelayanan rumah sakit (berobat), dan terbagi menjadi 5 bagian yaitu sesuai dengan kabupaten yang ada. Antara lain : Daerah Kota, Bantul, Kulon progo, Sleman, dan Gunung kidul. Mengingat adanya penggolongan daerah yang dilakukan untuk pengambilan sample, oleh sebab itu metode sample yang diambil dalam penelitian ini adalah proporsional random sampling.

\section{Ketidakpuasan (Y)}

Ketidakpuasan layanan merupakan suatu hal yang tidak diinginkan oleh konsumen atau pun pelanggan. Indikator ketidakpuasan ini mempunyai 4 instrumen di dalamnya, yaitu karyawan selalu menampilkan pelayanan yang ramah, karyawan selalu menampilkan pelayanan yang cepat, perusahaan bersedia mengembalikan uang atas ketidakpuasan layanan, dan instrumen terakhir yang berbunyi perusahaan berusaha selalu melakukan penanganan sesuai uang dikeluarkan oleh pengunjung. Indikator pengukuran diadopsi dari Yuliati dan Widyawati (2005).

\section{Lokasi (X1)}

Lokasi merupakan area dimana suatu perusahaan jasa atau manufaktur berada yang bisa menggambarkan dengan jelas keadaan yang sesungguhnya dan bisa di ukur keberadaannya dengan beberapa hal. Indikator lokasi ini mempunyai 7 instrumen di dalamnya, yaitu: pengunjung dapat dengan mudah untuk mencapai lokasi, pengunjung dapat dengan mudah untuk memperoleh transportasi umum, lapangan parkir yang dimiliki cukup luas sehingga memudahkan untuk pengunjung, tingginya tingkat keamanan parkir karena adanya penjagaan yang ketat, tingginya tingkat kenyamanan parkir yang disebabkan oleh tempat yang tidak panas, pengunjung merasa bahwa pelayanan yang diberikan oleh staf parkir terkategori baik, dan fasilitas yang dimiliki bisa di kategorikan lengkap. Ketujuh instrumen yang dimiliki ini diadopsi dari Nurendah dan Mulyana (2012).

\section{Kegagalan layanan (X2)}

Kegagalan layanan merupakan layanan yang tidak sesuai kebutuhan atau yang tidak diperlukan oleh pelanggan sehingga berdampak kepada ketidakpuasan pelanggan. Indikator kegagalan layanan ini mempunyai 2 instrumen di dalamnya, yaitu: Pencegahan kegagalan layanan dan pemulihan kegagalan layanan. Pencegahan kegagalan layanan terdapat 3 pernyataan yang dikeluarkan yaitu 
karyawan berusaha keras untuk mencegah timbulnya masalah-masalah pelanggan, karyawan berusaha sedapat mungkin mencegah atau mengantisipasi masalah-masalah pengunjung dari pada bereaksi ketika masalah muncul dan karyawan secara aktif mendengarkan pengunjung. Untuk pemulihan kegagalan layanan terdapat 4 pernyataan yang dikeluarkan yaitu karyawan memiliki system penanganan keluhan pengunjung yang sangat baik untuk menindak lanjuti layanan, karyawan membentuk kelompok pemecahan masalah untuk meningkatkan kemampuan dalam melayani kegagalan layanan, karyawan menyediakan layanan tindak lanjut untuk menjamin bahwa pelayanan dilakukan secara tepat dan yang terakhir karyawan memberikan garansi pelayanan yang jelas bagi setiap pengunjung. Kedua instrument diatas diadopsi dari Lytle (1998).

\section{Keluhan (X3)}

Keluhan merupakan bentuk ketidaksesuaian layanan yang diwujudkan dengan mengungkapkannya (suatu bentuk aduan) kepada perusahaan, orang lain atau diri sendiri dengan menggerutu. Indikator keluhan ini mempunyai 13 instrumen di dalamnya yang diadopsi dari Peraturan Menteri negara pendayagunaan aparatur negara nomor 13 tahun 2009.

\section{Ketrampilan (X4)}

Ketrampilan merupakan kemampuan yang dimiliki oleh karyawan yang nantinya dapat dijadikan sebagai sarana untuk memberikan pelayanan yang lebih baik. Indikator ketrampilan ini mempunyai 2 instrumen di dalamnya, yaitu : instrument pertama, pelatihan layanan yang adopsi dari Lytle (1998) : pengunjung merasa karyawan memberikan pelayanan dengan kualitas tinggi, karena karyawan sudah mendapatkan pelatihan ketrampilan dari instansi, pengunjung merasa karyawan memberikan layanan dengan tingkat yang lebih baik ketika menghadapi pengunjung, karena karyawan sudah mendapatkan dorongan pelatihan dari instansi, dan pengunjung merasa karyawan berusaha mengidentifikasi dan memperbaiki sikap kepada pengunjung, karena karyawan yang mendapatkan pelatihan kerja. Instrumen kedua, keahlian yang diadopsi dari Brandy dan Cronin (2001) : pengunjung dapat meyakini bahwa karyawan memahami pekerjaan mereka, karyawan dapat menjawab pertanyaan pengunjung dengan cepat, dan para karyawan memahami bahwa pengunjung mengandalkan pengetahuan mereka untuk memenuhi kebutuhan pengunjung.

Pengukuran yang dilakukan pada setiap indikator penelitian ini menggunakan skala 1-5 untuk alternatif jawaban, yang termasuk di dalamnya adalah : Sangat setuju (point 1), Setuju (point 2), Netral (point 3), Tidak setuju (point 4) dan Sangat tidak setuju (point 5). 


\section{METODE PENELITIAN}

Deskripsi identitas responden

Jumlah responden yang dianalisis dalam penelitian ini berjumlah 122 orang, dengan mendistribusikan 220 kuesioner (respon rate 55,5\%), namun data yang digunakan dibatasi 100 .

Tabel IV.1. Presentase identitas responden

\begin{tabular}{lcc}
\hline Umur & Frekuensi (orang) & Prosentase $(\%)$ \\
\hline$<25$ tahun & 48 & 48 \\
26-35 tahun & 8 & 8 \\
$36-45$ tahun & 15 & 15 \\
$>45$ tahun & 29 & 29 \\
\hline Total responden & 100 & 100 \\
\hline Jenis kelamin & & \\
\hline Perempuan & 53 & 53 \\
Laki-laki & 47 & 47 \\
\hline Wilayah pengobatan & & \\
\hline Daerah kota & 21 & 21 \\
Bantul & 37 & 37 \\
Kulon progo & 7 & 7 \\
Sleman & 24 & 24 \\
Gunung kidul & 11 & 11 \\
\hline Pendidikan terakhir & & \\
\hline Tidak sekolah & 1 & 1 \\
SD & 23 & 23 \\
SLTP & 12 & 12 \\
SLTA & 52 & 52 \\
DIPLOMA & 7 & 7 \\
SARJANA & 5 & 5 \\
\hline Pekerjaan & & \\
\hline Tidak bekerja & 41 & 41 \\
Wiraswasta & 44 & 44 \\
Petani & 14 & 1 \\
PNS/TNI/POLRI & 1 & \\
\hline
\end{tabular}

Penelitian ini melakukan uji asumsi klasik yang terdiri dari normalitas, uji multikolinearitas, uji heteroskedastisitas dan uji autokorelasi

Gambar 1 . Hasil uji normalitas dengan normal probability plot

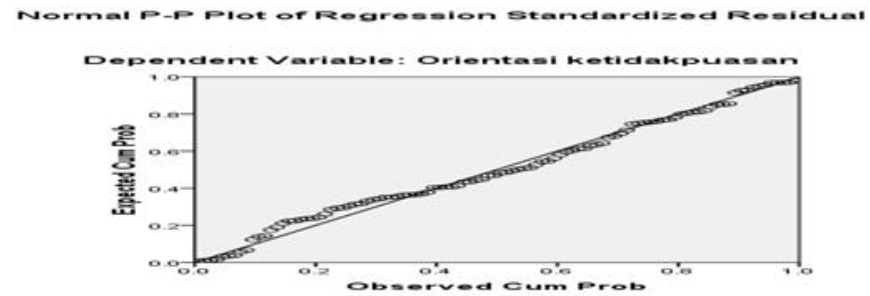

JPSB Vol.5 No.1, 2017 
Normalitas dilihat dengan normal p-plot yang mana data telah mendekati garis diagonal sehingga pendistribusiannya dapat dikatakan normal.

Tabel I Hasil uji multikolinearitas

\begin{tabular}{|c|c|c|c|}
\hline \multicolumn{4}{|c|}{ Coefficients $^{a}$} \\
\hline \multirow[b]{2}{*}{ Model } & & \multicolumn{2}{|c|}{$\begin{array}{c}\text { Collinearity } \\
\text { Statistics }\end{array}$} \\
\hline & & $\begin{array}{c}\text { Toleranc } \\
\mathrm{e}\end{array}$ & VIF \\
\hline 1 & (Constant) & & \\
\hline & Orientasi lokasi & .704 & 1.421 \\
\hline & $\begin{array}{l}\text { Orientasi kegagalan } \\
\text { layanan }\end{array}$ & .417 & 2.400 \\
\hline & Orientasi keluhan & .892 & 1.122 \\
\hline & Orientasi ketrampilan & .470 & 2.126 \\
\hline
\end{tabular}

a. Dependent Variable: Orientasi ketidakpuasan

Sumber : Data primer, diolah 2013

Dari hasil di atas dapat diketahui nilai VIF keempat variabel, yang ke semuanya itu lebih kecil dari 5, sehingga bisa di duga bahwa antarvariabel independen tidak terjadi persoalan multikolinearitas.

Gambar 2 Hasil uji heteroskedastisitas dengan scatterplot

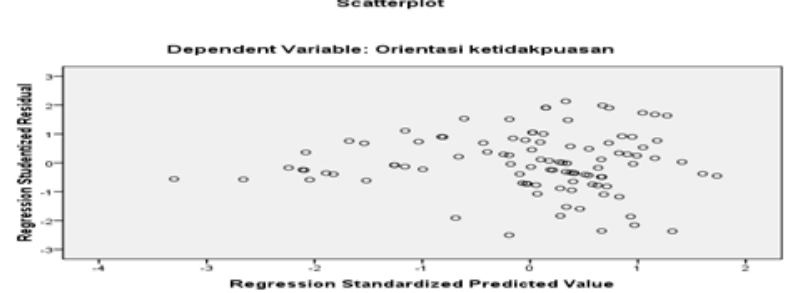

Sumber : Data primer, diolah 2013

Gambar 2 didapatkan titik-titik menyebar di bawah serta di atas sumbu $Y$, dan tidak mempunyai pola yang teratur. Hal ini mengindikasikan tidak terjadi heterokedastisitas pada model regresi sehingga model regresi layak dipakai.

Dari hasil pengolahan data diatas DW diperoleh angka 1.165 yang mana tabel 
Tabel 2 Hasil Uji autokorelasi

Model Summary

\begin{tabular}{lrrrrr}
\hline Model & $\mathrm{R}$ & R Square & $\begin{array}{c}\text { Adjusted R } \\
\text { Square }\end{array}$ & $\begin{array}{c}\text { Std. Error of } \\
\text { the Estimate }\end{array}$ & Durbin-Watson \\
\hline 1 & $.564^{\mathrm{a}}$ & .318 & .289 & 2.636 & 1.645
\end{tabular}

a. Predictors: (Constant), X4', X3', X1', X2'

b. Dependent Variable: $Y^{\prime}$

Sumber : Data primer, diolah 2013

Gambar 3 Daerah Autokolerasi

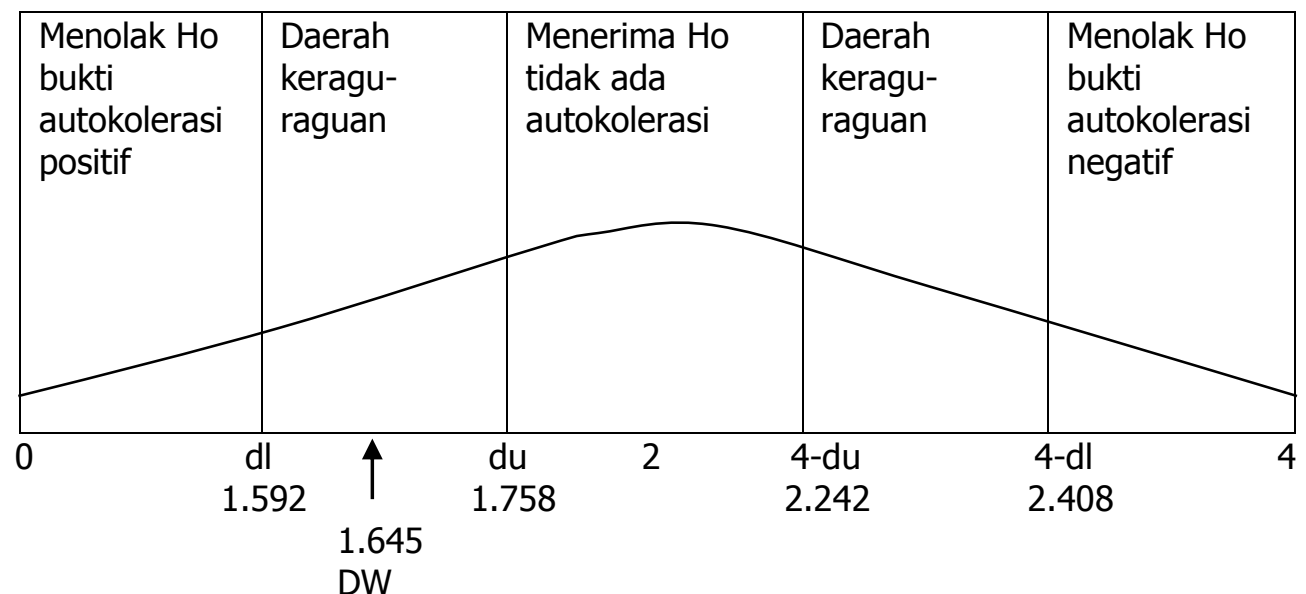

Hasil dari pengolahan data yang telah dihitung sebelumnya melalui Ms. Excel dengan menambahkan $\mathrm{X}^{\prime}{ }^{\prime}, \mathrm{X}^{\prime}{ }^{\prime}, \mathrm{X} 3^{\prime}, \mathrm{X}^{\prime}$, dan juga $\mathrm{Y}^{\prime}$. Setelah diujikan maka menghasilkan DW 1.645 yang mana sesuai dengan yang ditunjukkan oleh gambar 3 berada pada daerah keragu-raguan artinya bahwa tidak menghasilkan kesimpulan yang pasti.

Setelah dilakukan uji asumsi klasik maka peneliti melakukan analisis uji regresi linear berganda yang terdiri dari uji koefisiesn regresi secara bersamaan (Uji f) dan uji koefisien regresi secara parsial (uji t). Adapun hasil pengujian regresi adalah sebagai berikut: 
Tabel 3 Hasil uji koefisien regresi secara bersama-sama (uji F)

\begin{tabular}{|c|c|c|c|c|c|c|}
\hline \multicolumn{7}{|c|}{ ANOVA $^{\text {b }}$} \\
\hline Model & & $\begin{array}{l}\text { Sum of } \\
\text { Squares }\end{array}$ & $\mathrm{df}$ & Mean Square & $\mathrm{F}$ & Sig. \\
\hline \multirow[t]{3}{*}{1} & Regression & 300.042 & 4 & 75.010 & 6.642 & $.000^{\mathrm{a}}$ \\
\hline & Residual & 1072.798 & 95 & 11.293 & & \\
\hline & Total & 1372.840 & 99 & & & \\
\hline
\end{tabular}

a. Predictors: (Constant), Orientasi ketrampilan, Orientasi keluhan, Orientasi lokasi, Orientasi kegagalan layanan

b. Dependent Variable: Orientasi ketidakpuasan

Sumber : Data primer, diolah 2013

Uji $F$ digunakan untuk menguji ada tidaknya pengaruh variabel-variabel independen terhadap variabel dependen secara simultan (bersama-sama). Dikaitkan dengan hipotesis yang diajukan, yaitu:

a. Ho : tidak ada pengaruh antara lokasi, kegagalan layanan, keluhan dan ketrampilan secara bersama-sama terhadap Ketidakpuasan layanan.

b. Ha : ada pengaruh antara lokasi, kegagalan layanan, keluhan dan ketrampilan secara bersama-sama terhadap Ketidakpuasan layanan.

c. Pengujian pengaruh variabel bebas secara bersama-sama terhadap variabel terikatnya dilakukan dengan menggunakan uji F.

Hasil perhitungan statistik menunjukkan nilai $F$ hitung $(6,642)$ dengan $f$ tabel sebesar 2,467494. Tabel $\mathrm{F}$ ini didapat dari penghitungan yang dilakukan dengan menggunakan Ms. Excel yaitu dengan =finv $(0,05 ; 4 ; 95)$ sehingga mendapatkan hasil seperti yang telah disebutkan. Dari perolehan $\mathrm{F}$ hitung serta $\mathrm{F}$ tabel maka dapat dibandingkan hasilnya nilai $F$ hitung $>F$ tabel $(6,642>2,467494)$, maka dengan demikian Ho ditolak.

Tabel 4 Hasil uji koefisien regresi secara parsial (uji t)

Coefficients $^{\mathrm{a}}$

\begin{tabular}{|c|c|c|c|c|c|c|}
\hline \multirow[b]{2}{*}{ Mode } & & \multicolumn{2}{|c|}{$\begin{array}{l}\text { Unstandardized } \\
\text { Coefficients }\end{array}$} & $\begin{array}{l}\text { Standardize } \\
d \\
\text { Coefficients }\end{array}$ & \multirow[b]{2}{*}{$\mathrm{t}$} & \multirow[b]{2}{*}{ Sig. } \\
\hline & & $\mathrm{B}$ & Std. Error & Beta & & \\
\hline 1 & (Constant) & 1.406 & 2.546 & & .552 & .582 \\
\hline & Orientasi lokasi & -.003 & .098 & -.004 & -.032 & .974 \\
\hline & $\begin{array}{l}\text { Orientasi } \\
\text { kegagalan layanan }\end{array}$ & .030 & .117 & .036 & .257 & .798 \\
\hline & Orientasi keluhan & 167 & .033 & .482 & 5.018 & .000 \\
\hline
\end{tabular}


Orientasi

ketrampilan

.198

.140

$.186 \quad 1.410$

.162

a. Dependent Variable: Orientasi ketidakpuasan

Sumber : Data primer, diolah 2013

a. Pengujian koefisien regresi variabel Orientasi Lokasi

Ho : secara parsial tidak ada pengaruh antara lokasi dengan ketidakpuasan

$\mathrm{Ha}$ : secara parsial ada pengaruh antara lokasi dengan ketidakpuasan

Hasil pengujian dengan SPSS diperoleh untuk variabel X1 (Orientasi Lokasi) diperoleh nilai t hitung sebesar -0,032 dengan t tabel sebesar 1,985251. Hasil tersebut didapat dari penghitungan Ms. Excel dengan cara $=\operatorname{tinv}(0.05 ; 95)$. Sehingga mendapatkan hasil seperti yang telah disebutkan. Dari perolehan t hitung serta t tabel maka dapat dibandingkan hasilnya nilai -t hitung $>$-t tabel $(-0,032>-1,985251)$, maka dengan demikian Ho diterima.

b. Pengujian koefisien regresi variabel Orientasi kegagalan layanan

Ho : secara parsial tidak ada pengaruh antara kegagalan layanan dengan ketidakpuasan layanan.

$\mathrm{Ha}$ : secara parsial ada pengaruh antara kegagalan layanan dengan ketidakpuasan layanan.

Hasil pengujian dengan SPSS diperoleh untuk variabel X2 (Orientasi kegagalan layanan) diperoleh nilai $t$ hitung sebesar 0,257 dengan $t$ tabel sebesar 1,985251. Hasil tersebut didapat dari penghitungan Ms. Excel dengan cara $=\operatorname{tinv}(0.05 ; 95)$. Sehingga mendapatkan hasil seperti yang telah disebutkan. Dari perolehan $\mathrm{t}$ hitung serta $\mathrm{t}$ tabel maka dapat dibandingkan hasilnya nilai $\mathrm{t}$ hitung $<$ t tabel $(0,257<1,985251)$, maka dengan demikian Ho diterima.

c. Pengujian koefisien regresi variabel Orientasi keluhan

Ho : secara parsial tidak ada pengaruh antara keluhan dengan ketidakpuasan layanan.

$\mathrm{Ha}$ : secara parsial ada pengaruh antara keluhan dengan ketidakpuasan layanan.

Hasil pengujian dengan SPSS diperoleh untuk variabel X3 (Orientasi keluhan) diperoleh nilai t hitung sebesar 5,018 dengan t tabel sebesar 1,985251. Hasil tersebut didapat dari penghitungan Ms. Excel dengan cara $=\operatorname{tinv}(0.05 ; 95)$. Sehingga mendapatkan hasil seperti yang telah disebutkan. Dari perolehan $t$ hitung serta $t$ tabel maka dapat dibandingkan hasilnya nilai $t$ hitung $>t$ tabel (5,018>1,985251), maka dengan demikian Ho ditolak.

d. Pengujian koefisien regresi variabel Orientasi ketrampilan

Ho : secara parsial tidak ada pengaruh antara ketrampilan dengan ketidakpuasan layanan.

JPSB Vol.5 No.1, 2017 
$\mathrm{Ha}$ : secara parsial ada pengaruh antara ketrampilan dengan ketidakpuasan layanan.

Hasil pengujian dengan SPSS diperoleh untuk variabel X4 (Orientasi ketrampilan) diperoleh nilai $t$ hitung sebesar 1,410 dengan $t$ tabel sebesar 1,985251 . Hasil tersebut didapat dari penghitungan Ms. Excel dengan cara = tinv $(0.05 ; 95)$. Sehingga mendapatkan hasil seperti yang telah disebutkan. Dari perolehan $\mathrm{t}$ hitung serta $\mathrm{t}$ tabel maka dapat dibandingkan hasilnya nilai $\mathrm{t}$ hitung $<\mathrm{t}$ tabel $(1,410<1,985251)$, maka dengan demikian Ho diterima.

\section{PEMBAHASAN}

Hipotesis pertama dalam penelitian ini yaitu terdapat pengaruh yang kuat antara lokasi dan ketidakpuasan layanan tidak terdukung. Dikarenakan lokasi mempunyai beberapa poin yang perlu dikaji didalamnya, hal ini mengarah pada hubungan yang tidak signifikan. Kemudahan untuk mencapai lokasi, kemudahan untuk mendapatkan trasnportasi umum, luasnya lapangan parkir, keamanan parkir, kenyamanan parkir, pelayanan parkir yang baik, serta mengenai kelengkapan fasilitas tidak menjadi penyebab ketidakpuasan layanan. Banyak pengunjung yang tidak begitu memperdulikan mengenai lokasi yang ada, karena tujuan awal pengunjung yaitu untuk mendapatkan kesembuhan atau memperoleh apa yang mereka butuhkan ketika mereka memutuskan untuk berkunjung ke rumah sakit. Pada saat seorang pengunjung dalam keadaan sakit sehingga membutuhkan pengobatan atau penanganan dengan segera mereka tidak peduli dengan jauh atau dekatnya lokasi ataupun mudah sulitnya transportasi untuk mencapai lokasi tersebut.

Pernyataan diatas dikuatkan oleh beberapa peneliti Tjiptono (2004) mengatakan bahwa mood dan respon pelanggan dipengaruhi oleh lokasi, desain dan tata letak fasilitas jasa, Tjiptono dan Chandra (2005) lokasi fasilitas jasa merupakan salah satu faktor krusial yang berpengaruh terhadap kesuksesan suatu jasa, karena lokasi erat kaitannya dengan pasar potensial penyedia jasa, Nugroho dan Paramita (2009) keputusan pemilihan suatu lokasi juga mencerminkan komitmen jangka panjang perusahaan dalam hal keuangan. Kesemuanya ini merupakan beberapa penguatan hubungan lokasi dengan kepuasan, yang mana akan tidak berpengaruh terhadap ketidakpuasan layanan.

Kemudahan untuk mencapai lokasi (poin 1) disimpulkan memang pada kenyataannya lokasi penyedia jasa kesehatan merupakan tempat yang mudah didatangi oleh pengunjung. Hal ini memperkuat pernyataan Simamora (2001) yang mendeskripsikan kegunaan lokasi, dan produk dibuat pada tempat yang 
dapat didatangi konsumen. Kemudahan mendapatkan transportasi untuk menuju ke lokasi pengobatan (poin 2) menunjukkan bahwa tidak ada kendala mengenai transportasi untuk sampai ke temapat pengobatan, karena untuk masa sekarang ini banyak transportasi yang digunakan.

Simamora (2001) menyebutkan dalam pemaparannya transportasi merupakan salah satu hal-hal yang perlu direncanakan dalam manajemen distribusi yang kaitannya dengan peran penting sebuah lokasi. Namun pernyataan diatas berkaitan dengan bisnis jika di kaitkan dengan pelayanan jasa maka pengunjunglah yang merencanakan dalam arti mencari transportasi tersebut untuk menuju lokasi pengobatan. Selanjutnya pernyataan mengenai lapangan parkir yang dimiliki cukup luas sehingga memudahkan untuk pengunjung (poin 3), karena kemudahan pengunjung inilah banyak pengunjung merasa bahwa mereka tidak menemukan kesulitan untuk itu.

Pada poin 4 mengingatkan pada ungkapan Rymarzak (2012) bahwa keputusan terhadap lokasi itu tergantung pada parameter spesifik lokasi itu sendiri, dari penelitian ini mendapati keamanan parkir yang dilihat dari penjagaan yang ketat yang dapat menggambarkan hal tersebut. Poin selanjutnya yaitu poin 5 mengenai kenyamanan parkir, kenyamanan parkir ini merupakan gambaran khusus lokasi yang dimaksdukan. Untuk poin 6 tentang pelayanan baik staf parkir masuk didalam kspesifikan gambaran lokasi. Dan yang terakhir yaitu poin 7 kelengkapan fasilitas sangat penting bagi pengunjung. Seperti yang terlihat adanya kamar mandi, tempat ibadah, tempat parkir, ruang tunggu dan lain sebagainya menunjukkan bahwa tempat pengobatan tersebut memiliki fasilitas yang lengkap. Mengenai penyediaan sarana ini di ungapkan pula oleh Canel dan Das (2002) bahwa penyediaan sarana itu penting bagi perusahaan untuk bersaing di pasar global.

Lokasi memang mempunyai peran penting dalam suatu bisnis karena perlu mempertimbangkan letak strategis bisnis tersebut namun beda halnya dengan layanan jasa kesehatan. Dengan keadaan darurat seseorang akan tidak begitu peduli mengenai suatu lokasi karena akan berdampak buruk pada kesehatan jika saja masih memperhitungkan bagaimana lokasi itu ditempuh, atau bahkan memperdulikan jauh atau dekatnya suatu lokasi pengobatan. Penggambarannya akan semakin jelas ketika sesorang mempunyai penyakit kronis atau akut yang memang membutuhkan pertolongan medis dengan segera dan cepat, pada saat inilah pentingnya atau peran suatu lokasi akan dikesampingkan, karena akan lebih mengutamakan pertolongan kesehatannya. 
Rasa ketidakpuasan seseorang akan tidak dihiraukan karena tingginya tingkat kepentingan seseorang. Disini terlihat jelas bahwa lebih penting menyembuhkan penyakit yang dideritanya dengan segera daripada harus memilih-milih lokasi pengobatan yang akan dituju. Semakin lama seseorang mempertimbangkan lokasi yang akan dicapai, baik jarak, parkir, serta fasilitas umum akan semakin lama pula bentuk penanganan yang akan diterima. Hal ini dapat menjadi sebuah acuan bahwasannya suatu lokasi tidak bisa menjadi penghalang ketika seseorang akan memakai layanan kesehatan. Dengan demikian lokasi tidak bisa dikatakan sebagai pengaruh terhadap suatu ketidakpuasan layanan, karena mengingat lokasi bukan merupakan prioritas utama yang memang dicari serta dibutuhkan oleh pengunjung.

Hal ini sejalan dengan penelitian yang dilakukan oleh Adytomo (2006) mengenai pengaruh lokasi terhadap kepuasan pelanggan di hotel Grasia Semarang, hasil penelitiannya menyatakan bahwa lokasi berpengaruh terhadap kepuasan pelanggan. Selain itu juga ada penenlitian Ardhan (2010) tentang ananlisis pengaruh kualitas pelayanan, harga dan lokasi terhadap kepuasan pelanggan, hasil penelitian menunjukkan bahwa lokasi berpengaruh terhadap kepuasan.

Hipotesis kedua dalam penelitian ini yaitu terdapat pengaruh yang kuat antara kegagalan layanan dan ketidakpuasan layanan tidak terdukung. Ada beberapa pernyataan yang dimiliki oleh indikator kegagalan layanan, yang antara lain (poin 1) karyawan mencegah timbulnya masalah, (poin 2) karyawan berusaha sedapat mungkin mencegah atau mengantisipasi masalah-masalah pengunjung dari pada bereaksi ketika masalah muncul, (poin 3) karyawan secara aktif mendengarkan pengunjung, (poin 4) karyawan memiliki system penanganan keluhan pengunjung yang sangat baik untuk menindak lanjuti layanan, (poin 5) karyawan membentuk kelompok pemecahan masalah untuk meningkatkan kemampuan dalam melayani kegagalan layanan, (poin 6) karyawan menyediakan layanan tindak lanjuti untuk menjamin bahwa pelayanan dilakukan secara tepat, dan terakhir (poin 7) mengani karyawan memberikan garansi pelayanan yang jelas bagi setiap pengunjung. Banyak faktor yang menyebabkan kegagalan layanan terjadi, baik dari pengunjung sendiri, staf medis, ataupun peralatan yang dimiliki oleh penyedia jasa kesehatan.

Hal ini tidak bisa di elakkan jika memang sudah terjadi, namun tinggal bagaimana pihak penyedia jasa kesehatan dapat menangani hal ini agar tidak semakin memperburuk keadaan ataupun memperparah kegagalan layanan yang terjadi. Ditakutkan keadaan seperti ini bisa mempengaruhi pengunjung untuk tidak datang lagi berobat ketika mereka mengalami sakit untuk yang kedua atau 
bahkan setelahnya. Mengarah pada poin 5 yang menyebutkan mengenai meningkatkan kemampuan karyawan untuk melayani kegagalan layanan hal ini bisa menjadi suatu bentuk penanganan yang dilakukan oleh pihak rumah sakit setelah terjadinya suatu tindak kegagalan layanan. Kegagalan layanan ini sering terjadi ketika pengunjung masih berada di rumah sakit, sedangkan pihak pengunjungpun akan sepenuhnya menyalahkan apa yang terjadi kepada pihak rumah sakit. Mendasari apa yang disebutkan ada ungkapan dari Huang (2008) yang perlu menjadi perhatian, bahwa beberapa orang menganggap kegagalan yang dirasakan oleh pelanggan menjadi tanggung jawab perusahaan ketika mereka melihat bahwa kegagalan berada di bawah kendali perusahaan.

Namun pada peneltitian ini, selain mengangkat mengenai pencegahan atas kegagalan layanan juga mengenai pemulihan atas kegagalan layanan. Karena dari berbagai rumah sakit tidak membiarkan begitu saja ketika terjadi adanya kegagalan layanan. Sesegera mungkin rumah sakit melakukan tindak lanjut untuk mencegah semakin melebarnya kegagalan layanan yang terjadi. Mengingat bahwa sangat rawannya pelayanan jasa yang dilakukan karena berkaitan erat dengan sector kesehatan bukan semata karena bisnis, yang menyebabkan banyak rumah sakit yang harus memberikan kompensasi yang seimbang karena adanya kegagalan layanan. Ketika terjadi kegagalan layanan yang parah, perusahaan jasa harus mempertimbangkan kompensasi secara penuh (Noone, 2012).

Hasil peneltitian menunjukkan bahwa tingkat kegagalan layanan yang dirasakan oleh pengunjung masih berada dalam taraf yang wajar. Hal ini dapat diminimalisir oleh pihak rumah sakit karena mereka sadar sepenuhnya dalam memberikan layanan jasa tidak akan selalu lancar tanpa mengalami kegagalan sedikitpun, untuk itu banyak rumah sakit yang sebelum adanya kegagalan layanan mengadakan pencegahan. Pencegahan kegagalan layanan dapat dijumpai dari pelayanan karyawan yang diberikan, karyawan akan lebih berusaha untuk mencegah timbulnya masalah, mengantisipasi reaksi pengunjung, serta karyawan secara lebih aktif dalam mendengarkan apa yang dibutuhkan oleh pengunjung ketika pengunjung memutuskan untuk memakai jasa kesehatan rumah sakit. Selain dari pada itu, pihak rumah sakit mencanangkan untuk melakukan tindakan pasca kegagalan layanan.

Sebaik mungkin tindakan yang dilakukan semata ingin focus pada kepuasan yang akan dirasakan oleh pengunjung. Sebaliknya, pihak rumah sakit selalu mengoptimalkan dalam pemberian jasa kesehatan agar tidak terjadi ketidakpuasan layanan. Karena ketidakpuasan pengunjung merupakan mimpi 
buruk bagi penyedia jasa kesehatan. Berdasarkan hasil penenltiian, kegagalan pelayanan tidak menjadi salah satu faktor penyebab ketidakpuasan layanan. Hal ini mirip dengan penelitian yang dilakukan oleh Svari dan Svensson (2010 yang menghasilkan kegagalan layanan dapat membangun keadilan layanan. Selain itu Cunha (2009), kegagalan layanan mempunyai pengaruh positif terhadap pemulihan layanan, Lee (2010) bahwa kegagalan layanan berpengaruh terhadap keadilan.

Hipotesis tiga dalam penelitian ini terdapat pengaruh yang kuat antara keluhan dan ketidakpuasan layanan terdukung. Indikator keluhan dalam penenlitian ini, terdapat 13 poin yang antara lain : poin (1) pengunjung mendapatkan pelayanan yang adil dengan pengunjung lain, yang terlihat dengan adanya kesamaan dalam pelayanan. Padahal sebagaian pengunjung menilai pernyataan diatas yang mengakibatkan mereka mengungkapkan keluhan. Mengungkap soal kesopanan ini masuk kepada sikap seorang karyawan kepada pengunjung. Semakin sopan seorang karyawan dalam menghadapi pengunjung maka semakin kecil pengunjung akan memunculkan suatu keluhan. Ungkapan tersebut dikuatkan dengan ungkapan Majid (2009) yang juga mengutarakan mengenai beberapa hal yang menjadi penyebab keluhan terhadap layanan, yaitu disebutkan di bab II pada point 4 yang menyatakan bahwa seseorang berlaku tidak sopan atau tidak membantu terhadap mereka.

Poin (2) pengunjung mendapati prosedur pelayanan yang jelas dan tidak berbelit-belit. Situasi ini menunjukkan bahwa pihak pemberi jasa kesehatan dalam memberika prosedur pelayanan tidak jelas dan berbelit-belit, mengingat banyak pengunjung yang mengajukan keluhan terkait pelayanan tersebut. Hal ini berarti bahwa pemberi layanan kurang dalam memberikan pelayanan terkait dengan prosedur yang harus dilakukan. Inilah yang menjadi salah satu alasan pengunjung bisa mengajukan keluhan kepada pihak pemberi jasa kesehatan. Namun terkait dengan bahasan ini Majid (2009) mengungkapkan mengenai halhal yang bisa menjadi penyebab keluhan terjadi, yaitu telah diungkapkan pada poin 1 menyatakan bahwa pelayanan yang diharapkan dari kita tidak seperti yang mereka harapkan. Selama pihak rumah sakit masih memberikan pelayanan dengan baik katakanlah maksimal, keluhan pengunjung tidak akan terjadi dan sebaliknya.

Poin (3) tingkat pengetahuan kepastian biaya pelayanan bagi pengunjung tinggi karena adanya transparasi biaya. Hal ini telah mengisyaratkan bahwa pemberi jasa kesehatan harus lebih meningkatkan pelayanan terkait dengan pemberian kepastian biaya pelayanan bagi pengunjung. Dengan adanya ketidak setujuan 
pengunjung yang tinggi banyak bermunculan pula keluhan pengunjung terkait pelayanan yang diberikan. Banyaknya keluhan yang muncul secara tidak langsung juga berpengaruh terhadap karyawan-karyawannya. Banyak pengunjung yang mengeluhkan hal ini karena transparasi biaya sekarang ini tidak bisa dijadikan sebagai acuan biaya. Namun disisi lain bisa diambil segi positifnya, karena ketika keluhan-keluhan seperti ini bermunculan maka banyak karyawan akan berusaha memperbaiki layanan yang mereka berikan kepada pengunjung yang melakukan pengobatan ataupun sebatas check-up.

Seperti yang telah diungkapkan oleh Sugiarto (2002) yang mana menyebutkan bahwa dengan adanya keluhan para petugas juga akan menjadi lebih profesional dalam bekerja. Poin (4) pengunjung merasa adanya tanggung jawab karyawan pelayanan yang baik. Hal ini berarti bahwa pihak pemberi jasa kesehatan kurang baik terkait tanggung jawab karyawan dalam memberikan pelayanan. Kurangnya pelayanan dalam tanggung jawab karyawan merupakan salah satu faktor penyebab timbulnya keluhan yang dilakukan oleh pengunjung. Untuk mengurangi keluhan pengunjung akibat dari kurangnya tanggung jawab karyawan perlu dilakukannya suatu penanganan agar keluhan tersebut tidak menjadi masalah untuk pemberi jasa kesehatan. Mengingat ungkapan Tjipto dan Chandra (2005) mengenai sistem keluhan dan saran. Dianjurkan untuk para pemberi jasa kesehatan perlu menyediakan kesempatan dan akses yang mudah dan nyaman bagi pelanggannya guna menyampaikan saran, kritik, pendapat dan keluhan mereka.

Selain dari pada itu, terdapat poin (5) pengunjung merasa adanya kedisiplinan karyawan pelayanan yang baik, Penyangkalan atas pernyataan diatas dapat diartikan bahwa pihak pemberi jasa kesehatan yang kaitannya dengan kedisiplinan karyawan kurang baik. Keadaan yang menjadi kewaspadaan pihak pemberi jasa, dimana banyak responden yang menyetujui kurangnya kedisiplinan karyawan. Ketidaksetujuan responden inilah yang berujung pada munculnya keluhan pengunjung atas apa yang mereka temukan dilapangan pada saat merasakan jasa kesehatan. Keadaan seperti ini juga diungkapkan oleh Ndubisi dan Ling (2006) yang menyatakan bahwa ciri pelanggan yang mengisyaratkan tidak puas terhadap pelayanan terkait keluhan seperti perilaku pengaduan masyarakat (yaitu mengeluh kepada organisasi).

Poin (6) pengunjung merasa adanya kewajaran biaya pelayanan yang telah diberikan. Hal ini menunjukkan penyangkalan terhadap pernyataan tersebut karena banyak responden yang memberikan jawaban tidak setuju. Dengan demikian adanya keluhan seperti ini perlu segera ditangani oleh pihak yang 
bersangkutan. Penanganan atas keluhan yang disarankan oleh Mitchell (1993) untuk menggunakan sistem komputerisasi dalam pelaksanaanya, supaya memudahkan pihak yang bersangkutan untuk menganalisis keluhan. Poin (7) kemampuan karyawan dalam melayani pengunjung terkategori baik. Pengunjung merasa bahwa pihak pemberi jasa kemampuannya kurang baik dalam melayani pengunjung dan keluhan pengunjung bisa di minimalisir dengan baiknya kemampuan karyawan dalam memberikan pelayanan. Dapat diamati bahwa pihak pemberi jasa kesehatan seharusnya sadar sadar terhadap tugasnya dalam pekerjaan, agar dapat menangani sebuah keluhan dari pengunjung. Seperti yang dilontarkan oleh Sugiarto (2002) pada bab II yang berhubungan dengan pengenalan keluhan pelanggan, didalam poin 4 telah menyebutkan kesadaran para petugas akan fungsinya pada saat melayani pelanggan.

Poin (8) lengkapnya kejelasan karyawan dalam melayani keperluan pengunjung. Hal ini dapat digambarkan bahwa pihak pemberi jasa kesehatan dalam memberikan pelayanan terkait dengan kejelasan karyawan dalam melayani keperluan pengunjung dapat diukur tidak memuaskan. Hal seperti inilah yang bisa menjadi penyebab keluhan pengunjung. Keadaan seperti ini juga dikuatkan oleh ungkapan Sugiarto (2002) mengenai kategori keluhan, yang terdapat pada poin attitudinal complaint (keluhan akibat sikap petugas). Sikap disini bisa diartikan juga seperti kurangnya kejelasan karyawan dalam melayani keperluan pengunjung. Pada poin (9) mengenai tingginya keamanan pelayanan dalam melayani pengunjung. Keragu-raguan (netral) serta ketidak setujuan responden terhadap pernyataan yang telah diberikan mengartikan bahwa pihak pemberi jasa kesehatan dapat dibilang dalam memberikan pelayanan terkait keamanan pelayanan kurang memuaskan pengunjung. Hal ini bisa mengakibatkan banyaknya keluhan yang bermunculan yang berhubungan dengan keamanan pelayanan. Banyak keluhan yang muncul pada saat memburuknya pelayanan kesehatan maka tidak bisa diartikan juga sebagai suatu penghinaan untuk pihak yang bersangkutan.

Seperti yang diungkapkan oleh Sugiarto (2002) yang menyatakan bahwa keluhan pelanggan bukan berarti penghinaan terhadap produk perusahaan, melainkan merupakan suatu alat koreksi yang efektif yang akan membuat perusahaan semakin matang. Poin (10) cepatnya pelayanan karyawan dalam melakukan tugas-tugasnya. Banyak responden yang mengungkapkan ketidaksetujuan atas pernyataan tersebut, sehingga ini merupakan salah satu faktor penyebab terjadinya suatu keluhan pengunjung. Hal ini dapat diartikan bahwa pihak pemberi jasa kesehatan lambat pelayanan karyawan dalam melakukan tugas- 
tugasnya, selain itu juga dapat dikategorikan tidak memuaskan pengunjung. Dengan pengunjung merasa tidak puas terhadap pelayanan karena lambatnya pelayanan maka akan menyebabkan keluhan pengunjung. Hal terburuk bahkan pengunjung akan melakukan meminta ganti rugi. Seperti yang diungkapkan oleh Tjiptono (2000) yang menyatakan bahwa kebanyakan orang dalam mengungkapkan keluhan dengan cara langsung atau terkadang meminta ganti rugi kepada perusahaan yang bersangkutan.

Selanjutnya yaitu poin (11) yang menyatakan tentang pengunjung merasa tingginya tingkat kesopanan dan keramahan karyawan dalam memberikan pelayanan. Hal ini menunjukkan pihak pemberi jasa kesehatan sopan dan ramah dalam memberikan pelayanan dan bisa dikategorikan tidak puas karena banyak yang menyangkal atau menolak atas pernyataan tersebut. Dalam bahasan ini dapat dikatakan bahwa pernyataan tersebut menjadi penyebab keluhan. Mengingat bahwa keluhan itu sendiri merupakan sebuah harapan yang tidak terpenuhi (Barlow dan Moller, 1996). Poin (12) adanya pemberitahuan persyaratan pelayanan oleh karyawan kepada pengunjung. Hal ini menunjukkan pihak pemberi jasa kesehatan tidak mengadakan pemberitahuan persyaratan pelayanan oleh karyawan kepada pengunjung, maka ini akan menimbulkan suatu keluhan yang berhubungan dengan pelayanan yang diberikan mengingat bahwa pemberitahuan persyaratan merupakan salah satu tugas pelayanan yang harus di jalankan oleh karyawan. Dikuatkan dengan ungkapan Sugiarto (2002) mengenai kategori keluhan, yang menyatakan bahwa suatu keluhan pelanggan yang datang

Poin (13) adanya kepastian jadwal pelayanan yang diberikan oleh instansi. Banyak juga responden yang menyatakan bahwa suatu keoastian itu menjadi syarat penting mereka dalam menggunakan suatu jasa hingga selesai penggunaanya. Tentunya hal yang demikian akan menimbulkan suatu keluhan pengunjung. Keluhan pengunjung tidak dapat diabaikan begitu saja oleh pihak rumah sakit atau penyedia jasa kesehatan. Hal ini menyangkut kepuasan serta ketidakpuasan pengunjung dalam menggunakan jasa kesehatan. Dalam tingkatan wajar apa yang dikeluhkan oleh seorang pengunjung akan tidak menjadi beban masalah bagi rumah sakit, namun jika yang wajar ini menjadi parah sehingga banyak yang beranggapan bahwa pihak rumah sakit memberikan pelayanan yang tidak memuaskan.

Dalam jangka waktu yang tidak pendek akan terasa perubahan bagi rumah sakit, bisa terlihat dengan menurunnya pengunjung yang datang. Akan lebih baik jika rumah sakit lebih menjaga kepuasan pengunjung agar supaya kelangsung rumah 
sakit lebih bisa terjamin juga. Walaupun rumah sakit merupakan lembaga tanpa laba, namun ketika rumah sakit terusik pelayanannya dan mendapatkan masalah dengan ketidakpuasan pengunjung yang pernah menggunakan jasa kesehatan tersebut akan berakibat burk bagi kelangsungan rumah sakit itu sendiri. Berdasarkan hasil penenlitian ini, keluhan merupakan faktor penyebab ketidakpuasan layanan. Hal ini mirip dengan penelitian yang dilakukan oleh Gruber (2009) yang menyatakan bahwa keluhan merupakan dampak positif terhadap kepuasan pelanggan. Selain itu juga ada penelitian Svari dan Svensson (2010) yang menyatakan bahwa keluhan bisa membangun keadilan layanan.

Hipotesis keempat yaitu terdapat pengaruh yang kuat antara keterampilan dan ketidakpuasan layanan tidak terdukung. Pada indikator ketrampilan mempunyai 6 poin yang antara lain, poin (1) pengunjung merasa karyawan memberikan pelayanan dengan kualitas tinggi, karena karyawan sudah mendapatkan pelatihan ketrampilan dari instansi. Dengan demikian dapat disimpulkan dari jawaban responden tersebut bahwa banyak responden yang memberikan jawaban ragu-ragu (netral) terhadap pernyataan. Hal ini menunjukkan perlu diadakannya peningkatan atas upaya tersebut.

Bahkan Huppertz (2007) mengungkapkan juga mengenai kemampuan karyawan, yang mana kemampuan karyawan merupakan garis depan yang penting untuk menyelesaikan keluhan pelanggan yang efektif. Poin (2) pengunjung merasa karyawan memberikan layanan dengan tingkat yang lebih baik ketika menghadapi pengunjung, karena karyawan sudah mendapatkan dorongan pelatihan dari instansi. Hal ini menunjukkan upaya pengembangan karyawan yang dilakukan oleh pihak pemberi jasa kesehatan memuaskan pengunjung terbukti dengan hasil sebaran kuesioner yang banyak menanggapi ragu-ragu dan setuju terhadap pernyataan tersebut. Pengembangan karyawan merupakan upaya untuk mendorong karyawan lebih maju (Sabarguna, 2011). Poin (3) pengunjung merasa karyawan berusaha mengidentifikasi dan memperbaiki sikap kepada pengunjung, karena karyawan yang mendapatkan pelatihan kerja. Hal yang demikian menunjukkan bahwa pihak pemberi jasa kesehatan telah melakukan perbaikan sikap kepada pengunjung. Dengan pembuktian yaitu adanya perbaikan sikap dalam penanganan keluhan dengan hasil yang memuaskan. Semua ini karena adanya pelatihan yang dilakukan untuk peningkatan ketrampilan karyawan.

Simamora (2001), menyatakan bahwa pegawai yang bertugas menangani keluhan harus terlatih agar dapat menyelesaikan keluhan pelanggan dengan cepat dan memuaskan. Poin (4) pengunjung dapat meyakini bahwa karyawan 
memahami pekerjaan mereka. Hal ini menunjukkan bahwa kebanyakan responden setuju terhadap pernyataan yang menerangkan mengenai keyakinan pengunjung bahwa karyawan paham terhadap pekerjaan (tugas) mereka. Bahkan Cadman (2013) menambahkan mengenai hal tersebut, karyawan memiliki ketrampilan yang jauh lebih dari apa yang menjadi tugasnya, dan sekarang terbuka luas untuk bisa lebih mengasah kemampuan mereka agar mempunyai kompetensi karyawan jangka panjang. Poin (5) karyawan dapat menjawab pertanyaan pengunjung dengan cepat. Hasil respon pengunjung menyatakan bahwa sejumlah responden kebanyakan memberikan tanggapan setuju terhadap pernyataan mengenai karyawan yang dapat menjawab pertanyaan pengunjung dengan cepat. Hal ini menunjukkan adanya ketrampilan karyawan yang cepat bisa menjadikan aset yang paling berharga bagi organisasi (Matsumoto et al., 2005). Dan yang terakhir poin (6) para karyawan memahami bahwa pengunjung mengandalkan pengetahuan mereka untuk memenuhi kebutuhan pengunjung. Berdasarkan pada tanggapan responden bahwa responden kebanyakan menyetakan setuju dengan kemampuan karyawan dalam memahami mengenai pengunjung yang sangat mengandalkan pengetahuan yang dimiliki oleh karyawan untuk memenuhi kebutuhan mereka. Pengetahuan karyawan ini sangat penting, mengingat bahwa karyawan dididik agar menjadi team work yang kuat (Sabarguna, 2011).

Ketrampilan karyawan tidak merupakan penyebab ketidakpuasan layanan. Dalam dunia kesehatan, karyawan tidak asal-asalan dalam melayani para pengunjung. Mereka sudah trampil dalam melakukan tugas-tugasnya. Pihak rumah sakit akan bertanggung jawab penuh atas ketrampilan yang dimiliki oleh karyawan, karena banyak rumah sakit yang memang memberikan arahan untuk bagaimana bersikap ketika terjadinya suatu keluhan pengunjung. Oleh sebab itu, dengan karyawan yang bekerja dengan keprofesionalan serta tidak asal-asalan inilah mengapa banyak pengunjung yang merasa puas terhadap pelayanan karyawan. $\mathrm{Hal}$ ini mirip dengan penelitian yang dilakukan oleh Gruber (2009) dan Hannitha (2013) yang sama-sama menyatakan bahwa ketrampilan mempunyai pengaruh terhadap kepuasan. Selain itu juga penelitian Cunha (2009) mengenai ketrampilan merupakan improvisasi dalam pemulihan layanan

\section{KESIMPULAN}

Berdasarkan pada uji t (uji koefisien regresi secara parsial) menunjukkan bahwa: 
1. Variabel orientasi lokasi (X1) tidak memiliki pengaruh yang kuat terhadap ketidakpuasan layanan dengan nilai $\mathrm{t}$ tabel sebesar $-1,985251$ dan nilai $\mathrm{t}$ hitung sebesar $-0,032$ dengan tingkat signifikansi 0,974.

2. Variabel orientasi kegagalan layanan (X2) tidak memiliki pengaruh yang kuat terhadap ketidakpuasan layanan dengan nilai $\mathrm{t}$ tabel sebesar 1,985251 dan nilai t hitung sebesar 0,257 dengan tingkat signifikansi 0,798.

3. Variabel keluhan (X3) memiliki pengaruh yang kuat terhadap ketidakpuasan layanan nilai t tabel sebesar 1,985251 dan nilai t hitung sebesar 5,018 dengan tingkat signifikansi 0,000 .

4. Variabel ketrampilan (X4) tidak memiliki pengaruh yang kuat terhadap ketidakpuasan layanan dengan nilai t tabel sebesar 1,985251 dan nilai t hitung sebesar 1,410 dengan tingkat signifikansi 0,162.

Berdasarkan pada uji $\mathrm{f}$ (uji koefisien regresi secara bersama-sama) menunjukkan bahwa orientasi lokasi, orientasi kegagalan layanan, orientasi keluhan, orientasi ketrampilan mempunyai pengaruh yang signifikan terhadap ketidakpuasan layanan dengan nilai $t$ tabel sebesar 2,467494 dan nilai t hitung sebesar 6,642 dengan tingkat signifikansi 0,000 . Pada penelitian ini dari ke-4 variabel yang diangkat, variabel yang paling dominan mempengaruhi ketidakpuasan layanan yakni variabel keluhan.

\section{SARAN PENELITIAN YANG AKAN DATANG}

Perlu dilakukan penelitian lebih lanjut terhadap variabel selain orientasi lokasi, orientasi kegagalan layanan, orientasi keluhan, orientasi ketrampilan yang dapat mempengaruhi ketidakpuasan layanan pada sektor kesehatan di D.I. Yogyakarta. Karena diharapkan nantinya penelitian yang mengangkat ketidakpuasan ini bisa lebih memperoleh hasil yang sempurna dan dapat berkembang.

Untuk penelitian yang akan datang disarankan untuk meneliti sektor lain selain kesehatan yang mungkin mengalami permasalahan yang hampir sama dengan sektor kesehatan. Hal ini dapat dijadikan pembanding sekaligus sebagai pelengkap atas penelitian ini.

\section{DAFTAR PUSTAKA}

Adytomo, Yudith. (2006), Pengaruh Lokasi dan Pelayanan Terhadap Kepuasan Pelanggan di Hotel Grasia Semarang. Thesis Tidak Dipublikasikan. Universitas Diponegoro, Semarang. 
Ardhan, oldy. (2010), Analisis pengaruh kualitas pelayanan, harga dan lokasi terhadap kepuasan pelanggan. Skripsi tidak dipublikasikan. Universitas Diponegoro, Semarang.

Barlow, J. and Moller, C. (1996), A complain is a gift. Berrett-koehler publishers.

Bell, C. (2007), "Using employee volunteering programs to develop leadership skills", Development and Learning in Organizations, Vol. 21 Iss: 1, pp.6 $-8$

Berry, L.L. and Parasuraman, A. (1991), Marketing Services - Competing Through Quality, The Free Press, New York, NY.

Bitner, M.J., Booms, B.H. and Tetreault, M.S. (1990), "The service encounter: diagnosing favorable and unfavorable incidents source", Journal of Marketing, Vol. 54 No. 1, pp. 71-84.

Blodgett, J.G., Hill, D.J. and Tax, S.S. (1997), "The effects of distributive, procedural, and interactional justice on postcomplaint behavior", Journal of Retailing, Vol. 73 No. 2, pp. 185-210.

Bull, A. O. (1994), "Pricing a Motel's Location", International Journal of Contemporary Hospitality Management, Vol. 6 Iss: 6, pp.10 - 15

Cadman, C. (2013), "Training is now more than simply ticking the right boxes: Organizations build the right skills through targeted employee development", Human Resource Management International Digest, Vol. 21 Iss: 1, pp.34 - 37

Canel, C. dan Das, S.R. (2002), "Modeling global facility location decisions: integrating marketing and manufacturing decisions", Industrial Management \& Data Systems, Vol. 102 Iss: 2, pp.110 - 118

Clarkson, R.M., Hill, C.M. Clarke and Robinson, T. (1996), "UK supermarket location assessment", International Journal of Retail \& Distribution Management, Vol. 24 Iss: 6, pp.22 - 33

Cunha, M.P.E. (2009), Improvisation in service recovery. Managing Service Quality Vol. 19 No. 6, 2009 pp. 657-669.

Gronroos, C. (1988), "New competition in the service economy: the five rules of service", International Journal of Operations \& Production Management, Vol. 8 No. 3, pp. 9-19.

Gronroos, C. (1988), "Service quality: the six criteria of good perceived service quality", Review of Business, Vol. 9, pp. 10-13.

Gruber, T., Szmigin, R., and Voss, R. (2009), "Handling customer complaints Effectively : A comparison of the value maps of female and male 
complainants", journal of Managing service Quality, Vol. 19 No. 6, pp. 636-656

Hart, C.W.L., Heskett, J.L. and Sasser, W.E. (1990), "The profitable art of service recovery", Harvard Business Review, July-August, pp. 148-56.

Hanitha, dan yunni. (2013), Pengaruh kompetensi pegawai terhadap kualitas pelayanan. Publikasi, Prodi Ilmu Pemerintahan FISIP UNTAN. Volume 1, Nomor 01 Tahun 1. Pontianak.

Hoffman, K.D. and Bateson, J.E. (1997), Essential of Service Marketing, Dryden Press, New York, NY.

Huang W.H. (2008), "The impact of other-customer failure on service satisfaction", International Journal of Service Industry Management, Vol. 19 Iss: 4, pp.521 - 536

Huppertz, J.W. (2007), "Firms' complaint handling policies and consumer complaint voicing", International Journal of Health Care Quality Assurance, pp 428-437

Kelley, S.W., Donnelly, J.H. and Skinner, S.J. (1990), "Customer participation in service production and delivery", Journal of Retailing, Vol. 66 No. 3, pp. 315-35.

Lee, E.J. (2010), Service failures in online double deviation scenarios: justice theory approach. Managing Service Quality Vol. 20 No. 1, pp. 46-69.

Luk, STK., dan Liu, B. (2013), "SERV*OR in China: testing the effect of service orientation on service skills performance", Journal of Services Marketing, Vol. 27 Iss: 1, pp.25 - 39

Lytle, R. S., P.W. Hom \& M.P Mokwa (1998), "Serv* OR : A Managerial Measure of organizational serice orientation", Journal Retailing, Vol. 74/ No. 4. PP . 455-489.

Majid, Suharto A. (2009), Customer service dalam bisnis jasa transportasi. Jakarta. Rajawali pers.

Matsumoto, I.T., Stapleton, J., Glass, J. and Thorpe, T. (2005) "Developing a framework to measure organizational and employee skills development in a professional engineering design consultancy", Construction Innovation: Information, Process, Management, Vol. 5 Iss: 1, pp.53 - 66

Mitchell, V.W. (1993), "Handling Consumer Complaint Information: Why and How?", Logistics Information Management, Vol. 6 Iss: 3, pp.20 - 26

Ndubisi, N.O. and Ling, T.Y. (2006), "Complaint behaviour of Malaysian consumers", Management Research News, Vol. 29 Iss: 1/2, pp.65 - 76 
Newman, K. (2001), interrogating SERVQUAL A critical assesment of service quality measurement in high street retail, international journal of bank marketing Vol 19/3 : 126-139.

Nikbin, D., Ismail,I., Marimuthu M. and Jarad, I.Y.A. (2011), "The impact of firm reputation on customers' responses to service failure: the role of failure attributions", Business Strategy Series, Vol. 12 Iss: 1, pp.19 - 29

Noone, B. M. (2012), "Overcompensating for severe service failure: perceived fairness and effect on negative word-of-mouth intent", Journal of Services Marketing, Vol. 26 Iss: 5, pp.342 - 351

Nugroho, Marno dan Paramita, Ratih. (2009), "Analisis Pengaruh Lokasi, Keanekaragaman Barang Terhadap Keputusan Berbelanja dan Loyalitas Konsumen di Carrefour Semarang", Jurnal Ekonomi dan Bisnis, Januari, Vol.10, No. 1

Nurendah, Yulia dan Mulyana, Mumuh. (2012), "Analysis of Retailer's Location and Store Image of Giant Botani Square Bogor", Jurnal Ilmiah Kesatuan, Vol 14, April 2012.

Peraturan Menteri Negara, pendayagunaan aparatur negara, nomor 13 tahun 2009 tentang pedoman peningkatan kualitas pelayanan publk dengan partisipasi masyarakat

Rymarzak, M. and Sieminska, E. (2012), "Factors affecting the location of real estate", Journal of Corporate Real Estate, Vol. 14 Iss: 4, pp.214- 225

Sabarguna, B.S. (2011), Pengembangan lanjutan rumah sakit : menuju rumah sakit kelas dunia. Salemba Medika. Jakarta,

Schoefer, K. and Diamantopoulos, A. (2008), "The role of emotions in translating perceptions of (in) justice into postcomplaint behavioral responses", Journal of Service Research, Vol. 11, pp. 91-103.

Setiadi, N.J. (2010), Perilaku konsumen : perspektif kontemporer pada motif, tujuan, dan keinginan konsumen, Kencana, Jakarta.

Simamora, B. (2001), Memenangkan pasar : dengan pemasaran efektif dan profitabel. Gramedia pustaka utama, Jakarta.

Smith, A.K., Bolton, R.N. and Wagner, J. (1999), "A model of customer satisfaction with service encounters involving failure and recovery", Journal of Marketing Research, Vol. 36 No. 3, pp. 356-72.

Stauss, B. and Seidel, W. (1998), "Prozessuale Zufriedenheitsermittlung und Zufriedenheitsdynamik bei Dienstleistungen", in Simon, $H$. and Homburg, C. (Eds), Kundenzufriedenheit, Konzepte - Methoden Erfahrungen, 3rd ed., Gabler, Wiesbaden. 
Sugiarto, E. (2002), Psikologi pelayanan dalam industri jasa. Gramedia pustaka utama. Jakarta.

Svari, S dan Svensson, G. (2010), A DIP-construct of perceived justice in negative service encounters and complaint handling in the Norwegian tourism industry. Managing Service Quality Vol. 20 No. 1, 2010 pp. 2645.

Tjiptono, F. (2000), Manajemen jasa, Andi, Yogyakarta.

Tjiptono, Fandy, (2004), Pemasaran Jasa, Malang: Bayumedia.

Tjiptono, Fandy dan Chandra, G. (2005), Service, Quality \& Satisfaction. Yogyakarta : Penerbit Andi.

Walker, L.J. Harrison. (2012), "The role of cause and affect in service failure", Journal of Services Marketing, Vol. 26 Iss: 2, pp.115 - 123

Weun, seungoog, beatty, sharon E, dan Michael A. Jones. (2004), The impact of service failure severity on service recovery evaluations and post recovery relationships. Journal of service marketing vol 18/2:133-146.

Winsted, K.F. (2000), "Service behaviors that lead to satisfied customers", European Journal of Marketing, Vol. 34 Nos 3/4, pp. 399-417.

Yuliati, L.N dan Widyawati. (2005), "Respon ketidakpuasan terhadap kualitas Dan pelayanan food court di kampus IPB. Media Gizi \& Keluarga"., Vol.29 (2): 88-95.

Zeithaml, velerie A dan Bitner, M.J. (2000), Services marketing: integrating customer focus accross the firm. New york : McGraw-Hill. 